\title{
Biofortification of Mungbean (Vigna radiata) using Iron- Enriched Organic Amendment
}

\author{
Umar Farooq1, Muhammad Akmal', Qadeer Ahmad², Zahid Akram², Adnan Arshad', Huma Qamar*', \\ Hafeez Ullah ${ }^{5}$, Muhammad Zubair ${ }^{4}$ and Muhammad Rizwan Khurshid ${ }^{4}$
}

${ }^{1}$ Department of Soil Science and SWC, PMAS Arid Agriculture University, Rawalpindi, Pakistan; ${ }^{2}$ Department of Plant Breeding and Genetics, PMAS Arid Agriculture University, Rawalpindi, Pakistan; ${ }^{3}$ College of Resources and Environmental Science, China Agricultural University, Beijing, 100193, China; ${ }^{4}$ Oilseeds Research Institute, Faisalabad, Pakistan; ${ }^{5}$ Department of Agronomy, University of Agriculture Faisalabad, Pakistan.

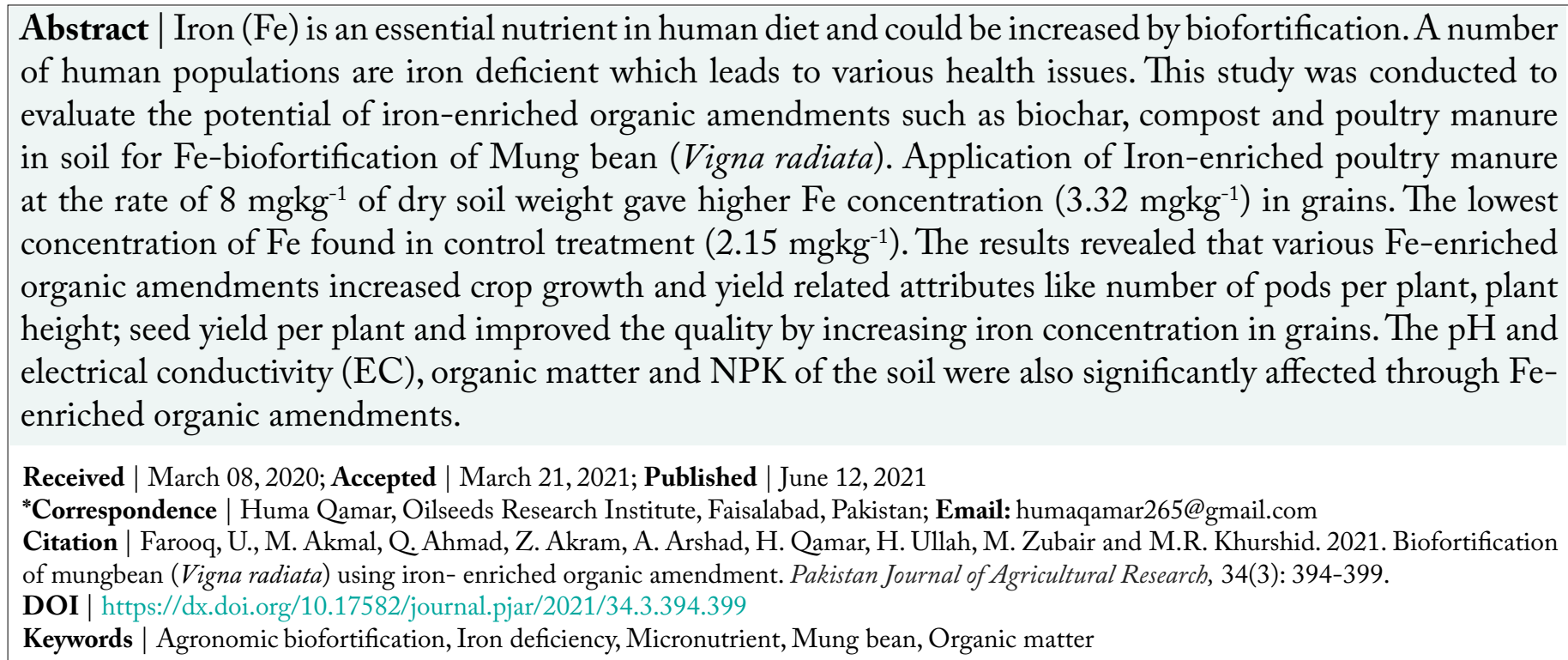

\section{Introduction}

$\mathrm{I}_{\mathrm{p}}^{\mathrm{sin}}$ (Fe) plays a major role in respiration, photosynthesis, absorption of sulfur and nitrogen fixation by plants. Lack of balanced diet intake is one of the major reasons behind the long time deficiency of iron especially in pregnant women and children residing in developing countries as they consume food which is easily available in less cost without any preference for balanced diet (Hunt, 2005; Rout and Sahoo, 2015; Semba, 2016). Fe deficiency is a serious concern which results in chlorosis, decrease in quantity and quality of the produce (Markle et al., 2007; Masuda et al., 2012; Foyer et al., 2016).
Through biofortification, staple crops could be enriched in vitamins and minerals nutrients by the process of plant breeding and agronomic practices (Bouis et al., 2017; Yunus et al., 2019). Biofortification can be utilized as a way to decrease specific nutritional deficiencies; such as iron, zinc and vitamin A among countries which have low per capita income.

Organic matter plays significant role in maintaining the soil health and soil structure. Organic matter improves water holding capacity of the soil, reduces soil and nutrient erosion and increases water holding capacity of soil (U.S Extension, 2019; Moe et al., 2019). Microorganisms (bacteria, fungi and others) 
help in converting the organic matter such as manure, dead leaves, food wastage, grass clipping sludge and paper into compost or humus (soil like material) which is called soil composting (Stan et al., 2009). Major component of organic matter which is formed by decomposition of organic matter is compost which balances the $\mathrm{pH}$ of the soil up to optimum level where soils are alkaline in nature (Rainbow and Wilson, 2002).

Water holding capacity could be maintained with Biochar (Abel et al., 2013). Biochar can help in improving soil porosity, soil based dissemination, nutrients preservation and availability. By this, less fertilizers and nutrients are required, while increasing carbon exclusion (Lal., 2011). Biochar and poultry manure also increase water holding capacity of the soil by electron exchange process. Ramzani et al. (2016) reported that the combined use of $\mathrm{Fe}$ and Biochar could be an effective way to improve yield and grain iron biofortification of grain crops especially in $\mathrm{pH}$ affected, calcareous type of soil.

The basic purpose of the present study was to examine the results of application of Iron enriched amendments on mung bean crop and assessing the success of biofortification.

\section{Materials and Methods}

Experiment was conducted in greenhouse at Research Farm of PMAS-Arid Agriculture University Rawalpindi, Pakistan in Rabi cropping season during 2017-18. Mung bean seed was obtained from National Agricultural Research Centre (NARC), Islamabad, Pakistan. Soil was obtained from research farm and filtered with sieve having $2 \mathrm{~mm}$ size and each experimental pot contained $5-\mathrm{kg}$ soil. Eight treatments were designed by following complete block design along with three replications. Fifteen plants were maintained in each pot. Treatments were; $\mathrm{T}_{1}=$ Control, $\mathrm{T}_{2}=\mathrm{Fe}\left(8 \mathrm{mgkg}^{-1}\right)$ of the dry soil weight, $\mathrm{T}_{3}=$ Biochar (1\% of the dry soil weight), $\mathrm{T}_{4}=$ Compost ( $1 \%$ of the dry soil weight), $\mathrm{T}_{5}=$ Poultry manure $(1 \%$ of the dry soil weight), $\mathrm{T}_{6}=\mathrm{Fe}$-enriched biochar (8 $\mathrm{mgkg}^{-}$ $\left.{ }^{1}\right)$ of the dry soil weight, $\mathrm{T}_{7}=\mathrm{Fe}$-enriched Compost $\left(8 \mathrm{mgkg}^{-1}\right)$ of the dry soil weight, $\mathrm{T}_{8}=\mathrm{Fe}$-enriched Poultry manure $\left(8 \mathrm{mgkg}^{-1}\right)$ of the dry soil weight.

Basic fertilizers; Nitrogen (N), Phosphorus (P) and Potassium (K) were applied with the ratio of 23:45:45 $\mathrm{kgha}^{-1}$, respectively. Before sowing, full doses of Phosphorus and Potassium along with half dose of Nitrogen was provided. Other half dose of Nitrogen was provided after 30 and 45 days of emergence in split doses. Plants were irrigated as and when required. Hoeing was done as per requirement.

Soil related parameters such as $\mathrm{pH}$, Electrical conductivity (EC), organic matter, NPK and soil iron concentration were analyzed when plants reached at maturity stage. Plant parameters, namely grain NPK, grain iron $(\mathrm{Fe})$, pods per plant, plant height and seed yield were recorded when plants reached at their maturity stage.

Grain samples were collected from each pot; air dried and grounded using electric grinder. One gram of powder sample was digested with digestion mixture in the digestion chamber at $300^{\circ} \mathrm{C}$. Grain iron concentration were determined by the atomic absorption spectrophotometer. Data of all attributes was statistically analyzed using computer software Statistix, version 8.1 .

\section{Results and Discussion}

Results of soil analyzed parameters shows low effect of various treatments on soil $\mathrm{pH}$. Results of different treatments indicates that in control conditions, soil $\mathrm{pH}$ is highest (7.8) and followed by Iron-enriched> poultry manure> Iron > Biochar > Iron-enriched biochar > compost > Iron-enriched compost. In Fe enriched compost, soil $\mathrm{pH}$ was low (7.5) due to microbial decomposition of organic compounds and production of organic acid (Sarir et al., 2005). The overall results indicated that effect of organic materials on $\mathrm{pH}$ of soil was significantly intermediate (Figure 1). There was not a big difference in soil EC ds $\mathrm{m}^{-1}$. Highest soil EC $\left(0.1990 \mathrm{dsm}^{-1}\right)$ was found in iron-enriched poultry manure and lowest EC was found in treatment where compost $\left(0.043 \mathrm{dsm}^{-1}\right)$ and iron-enriched compost treatments $\left(0.0348 \mathrm{dsm}^{-1}\right)$.

Poultry manure contains highest amount of nutrients. Application of poultry manure raises the soluble ions which is the main reason to increases the soil EC. The maximum concentration of $\mathrm{NO}_{3}-\mathrm{N}$ was found in Fe-enriched Poultry manure (12.133 mg $\mathrm{Kg}^{-1}$ ) and Fe-enriched Compost $\left(11.80 \mathrm{mg} \mathrm{Kg}^{-1}\right)$. In soil, $\mathrm{NO}_{3}-\mathrm{N}$ was found in least concentrations in control treatment and Iron fertilizer treatments because 
nitrogen volatilized or $\mathrm{NO}_{3}$ might have been leached down (Zhao et al., 2001; Pandey and Singh, 2016).

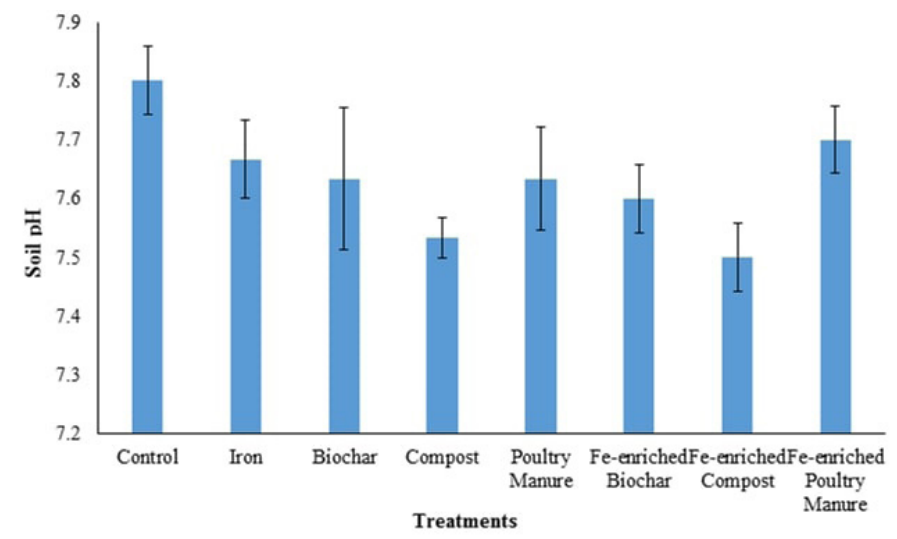

Figure 1: Effect of different organic ammendments on soil.

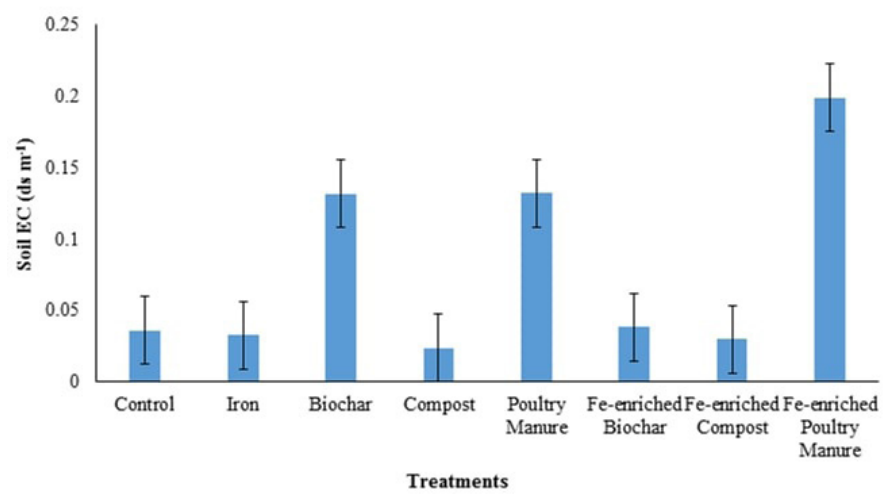

Figure 2: Effect of organic amendment on soil EC.

The maximum concentration of phosphorus in soil was found in Fe-enriched Poultry manure (5.16 $\left.\mathrm{mgkg}^{-1}\right)$ and Control $\left(3.4 \mathrm{mgkg}^{-1}\right)$ treatments. The enriched amendments improved the phosphorus more from other organic amendments. The manure amendments improve the soil fertility by reducing the losses and rescue the nutrients from their fixing in soil. Biochar contains different level of phosphorus after production from different feedstock. That form of phosphorus in the soil is easily taken up by the crops after decomposition (Miller et al., 2011).

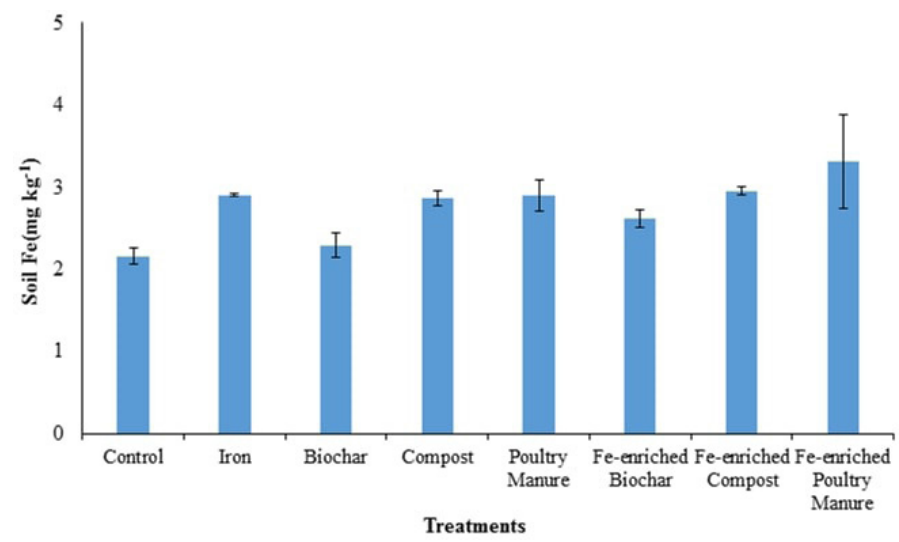

Figure 3: Effect of organic amendment on soil iron.
Soil iron under organic amendment

Soil iron: Iron $(\mathrm{Fe})$ in soil was affected positively by the application of various treatments (Figure 3). The treatment of $\mathrm{Fe}$-enriched poultry manure contains high value of $\mathrm{Fe}\left(3.3068 \mathrm{mgkg}^{-1}\right)$ and the lowest concentration of Fe found in Control $\left(2.1557 \mathrm{mgkg}^{-1}\right)$ treatment. Hartley et al. (2016) reported significant consequences of biochar application on soil micronutrients.

\section{Organic amendment effect on grain total nitrogen and phosphorous (\%)}

Nitrogen (\%) in grain: The results of different treatments on plant total nitrogen are given in the Figure 4. The maximum total nitrogen of plant was found in treatment of $\mathrm{Fe}$-enriched poultry manure $(2.01 \%)$. The minimum total nitrogen concentration was found in control $(1.51 \%)$ treatment, because of the absence of fertilizer or application of organic amendments.

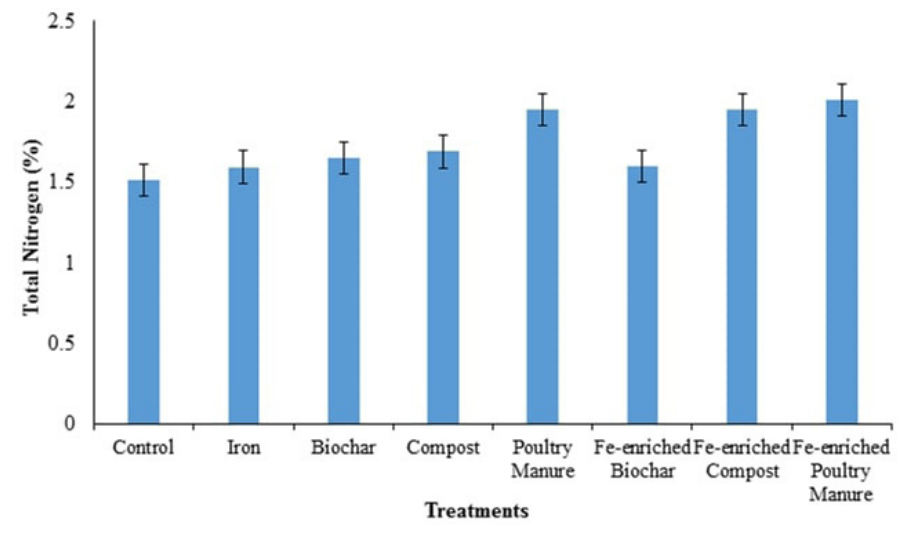

Figure 4: Effect of organic amendment on plant grain total nitrogen.

Phosphorous (\%) in grain: The data associated to the impact of various organic amendments on plant uptake of phosphorus are given in a Figure 5. The means are not significantly different from one another. The highest phosphorus concentrations uptake the plant by the application of Fe-enriched poultry manure (1.401\%) and Fe-enriched compost (1.38\%), respectively. Biochar had least effect on uptake of phosphorus by plant. Asai et al. (2009) also reported nitrogen application is more efficient than biochar treatment. The lowest concentrations of plant uptake phosphorus were found in the control and Iron ( $\mathrm{Fe}$ ) fertilizer treatments, because of absence of fertilizer or organic amendments application. Ahmad et al. (2007) revealed that organic manure can significantly reduce the soil $\mathrm{pH}$, as a result, producing various acids such as fulvic acid, humic acid, and ketoglutaric acid, eventually phosphorus uptake rises. 


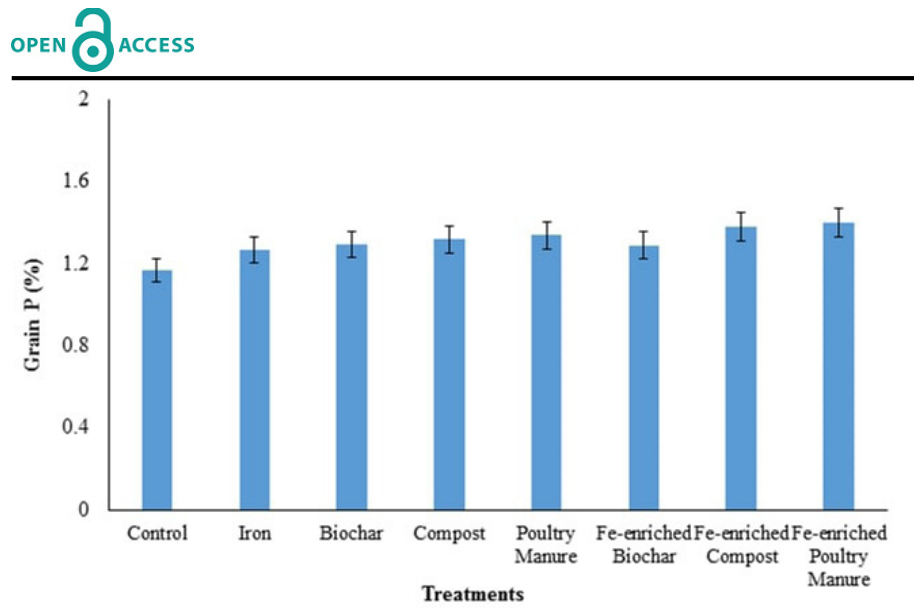

Figure 5: Effect of organic amendment on grain phosphorus.

Iron (\%) in grain: Effect of different organic amendments on grain iron $(\mathrm{Fe})$ concentration is shown in Figure 6. The highest Fe concentration $\left(122.96 \mathrm{mgkg}^{-1}\right)$ was noted in Fe-enriched poultry manure application, followed by control (50.923 $\left.\mathrm{mgkg}^{-1}\right)$ and single biochar treatment $(84.217 \mathrm{mgkg}$ ${ }^{1}$ ). Organic amendments play very important role in trace element availability. Makhabela and Warman (2005) also showed that organic amendments increased the nutrients for the plant uptake by enhancing micronutrients concentration of plants.

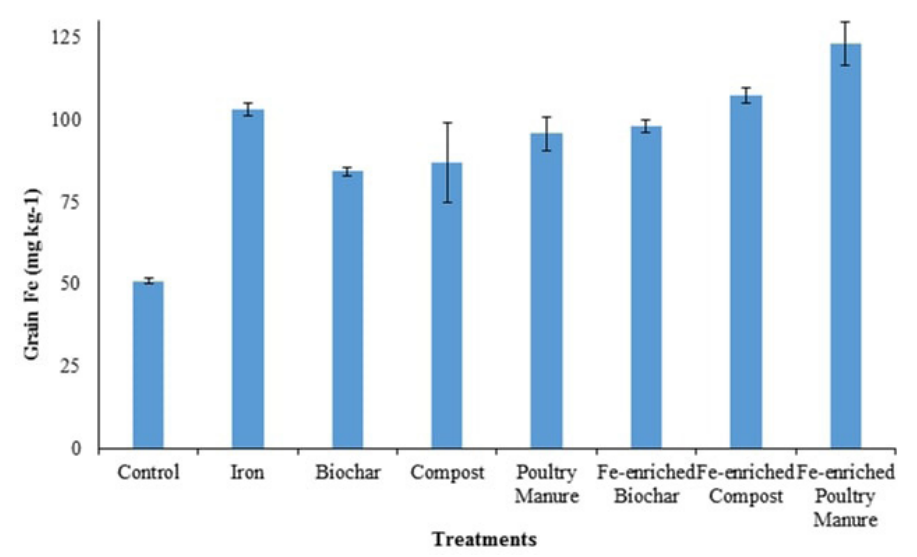

Figure 6: Effect of organic amendment on grain iron.

Organic amendment effect on plant height

Plant height $(\mathbf{c m})$ : The treatment of organic manure and iron treatments shows that the plant height means are not significantly different from one another (Figure 7). Maximum plant height was found in Fe-enriched Poultry manure $(28.00 \mathrm{~cm})$ and from single treatment, maximum plant height was found in poultry manure $(25.66 \mathrm{~cm})$. The application of poultry manure to soil increases the microbial activity which concentrated the decompositions and make nutrients available to plant for their uptake (Nayak and Vaidya, 2018). Brown et al. (1993) also found that iron enhanced the growth of mung bean crop.

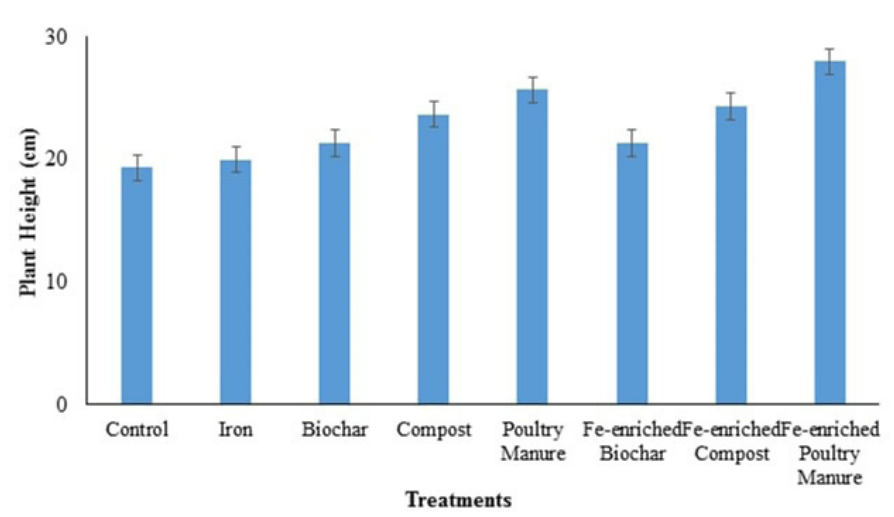

Figure 7: Effect of organic amendment on plant height.

\section{Conclusions and Recommendations}

Application of iron-enriched organic amendment improved the soil properties, plant growth, increased yield and $\mathrm{Fe}$ concentration of mung bean crop. Biofortification on industrial scale is need of the hour to prevent deficiency of micronutrients in mung bean. State should also play concrete role while incentivizing the biofortification in industry and market along with educating people to opt for fortified nutritious foods.

\section{Novelty Statement}

Human beings in developing countries are significantly Iron-deficient. This study provides an insight to cater the human needs.

\section{Author's Contribution}

Muhammad Akmal and Zahid Akram: Designed the study.

Umar Farooq and Qadeer Ahmad: Conducted the study.

Adnan Arshad and Huma Qamar: wrote the manuscript.

Hafeez Ullah and Muhammad Rizwan Khurshid: Statistically analyzed the data \& made graphical representation of data.

Muhammad Zubair: proofread the manuscript.

\section{Conflict of interest}

The authors have declared no conflict of interest.

\section{References}

Abel, S.A., A. Peters, S. Trinks, H. Schonsky, M. Facklam and G. Wessolek. 2013. Impact of biochar and hydrochar addition on water 
retention and water repellency of sandy soil. Geoderma, 202: 183-191. https://doi. org/10.1016/j.geoderma.2013.03.003

Ahmad, R., G. Jilani, M. Arshad, Z.A. Zahir and A. Khalid A. 2007. Bio-conservation of organic wastes for their recycling in agriculture: an overview of perspectives and prospects. Ann. Micro., 57: 471-479. https://doi.org/10.1007/ BF03175343

Asai, H., B.K. Samson, H.M. Stephan, K. Songyikhangsuthor, K. Homma, Y. Kiyono, Y. Inoue, T. Shiraiwaand and T. Horie. 2009. Biochar amendment techniques for upland rice production in Northern Laos 1. Soil physical properties, leaf SPAD and grain yield. J. Field Crops Res., 111: 81-84. https://doi. org/10.1016/j.fcr.2008.10.008

Bouis, H.E. and A. Saltzman. 2017. Improving nutrition through biofortification. A review of evidence from Harvest Plus, 2003 through 2016. Glob. Food Secur., 12: 49-58. https://doi. org/10.1016/j.gfs.2017.01.009

Brown, P.H., I. Cakmak and Q.Zhang. 1993. Form and function of zinc in plants. In: Robson, A.D. (ed.),Zinc in Soils and Plants. Kluwer Academic Publishers, Dordrecht. pp. 90-106. https://doi. org/10.1007/978-94-011-0878-2_7

Foyer, C.H., H.M. Lam, H.T. Nguyen, K.H. Siddique, R.K. Varshney, T.D. Colmer, W. Cowling, H. Bramley, T.A. Mori, J.M. Hodgson and J.W. Cooper. 2016. Neglecting legumes has compromised human health and sustainable food production. Nat. Plants, 2: 16112. https:// doi.org/10.1038/nplants.2016.112

Hartley, W., P. Riby and J. Waterson. 2016. Effects of three different biochars on aggregate stability, organic carbon mobility and micronutrient bioavailability. J. Environ. Manage., 181: 770-778. jenvman.2016.07.023

Hunt, J.R., 2005. Dietary and physiological factors that affect the absorption and bioavailability of Iron. Int. J. Vitam. Nutr. Res., 75: 375-384. https://doi.org/10.1024/0300-9831.75.6.375

Jamal, A., M.I. Khan, M. Tariq and M. Fawad. 2018. Response of mung bean crop to different levels of applied iron and zinc. J. Hortic. Plant Res., 3: 13-22. https://doi.org/10.18052/www. scipress.com/JHPR.3.13

Lal, R., 2011. Sequestering carbon in soils of agroecosystems. Food Policy, 36: 33-39. https://doi. org/10.1016/j.foodpol.2010.12.001

Makhabela, M.S. and P.R. Warman. 2005. The influence of municipal solid waste compost on yield. soil phosphorus availability and uptake by two vegetable crops grown in a Pugwash sandy loam soil in Nova Scotia. Agric. Eco. Environ., 106:57-67.https://doi.org/10.1016/j. agee.2004.07.014

Markle, W., M.A. Fisher and R.A. Smego. 2007. Understanding global health. McGraw-Hill Medicall, New York.

Masuda, H., Y. Ishimaru, M.S. Aung, T. Kobayashi, Y. Kakei, M. Takahashi, K. Higuchi, H. Nakanishi and N.K. Nishizawa. 2012. Iron biofortification in rice by the introduction of multiple genes involved in iron nutrition. Sci. Rep.,2:543.https://doi.org/10.1038/srep00543

Miller, M. T., Duvall, M. and Sohi, S. P. 2011. Localisation of nitrate in the rhizosphere of biochar-amended. soils. Soil Bio. Biochem., 43: 2243-2246.

Moe, K., A.Z. Htwe, T.T.P. Thu, Y. Kajihara and T. Yamakawa. 2019. Effects on NPK status, growth, dry matter and yield of rice (Oryza sativa) by organic fertilizers applied in field condition. J. Agric. 9: 109. https://doi. org/10.3390/agriculture9050109

Nayak, J.J. and D.A.C. Vaidya. 2018. Green manure in crop production and soil health. Int. J. Inno. Res. Sci. Eng. Tech., 7: 6.

Pandey, A.K. and M.K. Singh. 2016. Importance and uses of green manuring in field crops. Rashtriyakrishi. 11: 35-38.

Rainbow, A. and F.N. Wilson. 2002. Composting for soil improvement in the United Kingdom. Proc. $12^{\text {th }}$ Int. Soil Conserv. Organ. Conf. May 26-31, 2004. Beijing, China. pp. 63-67.

Ramzani,P.M.A.,M.Khalid,M.Naveed,R.Ahmad and M. Shahid. 2016. Iron biofortification of wheat grains through integrated use of organic and chemical fertilizers in $\mathrm{pH}$ affected calcareous soil. Plant Physiol. Biochem., 104: 284-293. https://doi.org/10.1016/j.plaphy.2016.04.053

Rout, G.R. and S. Sahoo. 2015. Role of iron in plant growth and metabolism. J. Agric. Sci., 3: 1-24. https://doi.org/10.7831/ras.3.1

Sarir, M.S., M. Sharif, Z. Ahmed and M. Akhlaq. 2005. Influence of different levels of humicacid application by various methods on the yield and yield components of maize. Sarhad J. Agric., 21: 75-81. 
Semba, R.D., 2016. The rise and fall of protein malnutrition in global health.Ann. Nutr.Metab., 69: 79-88. https://doi.org/10.1159/000449175

Stan, V., A. Virsta, E.M. Dusa and A.M. Glavan. 2009. Waste recycling and compost benefits. Rom. J. Bot. Hortic., 37: 9-13.

USDA, National Institute of Food and Agriculture. 2019. New Technologies for agriculture extension grant no. 2015-41595-24254.

WHO Report. 2018. Iron deficiency anaemia assessment, prevention, and control a guide for programmed managers. WHO/NHD/01.3 Distribution: General English only.
Yunus, F.M., C. Jalal, K. Afsana, R. Podder, A. Vandenberg and D.M.V. Della. 2019. Ironfortified lentils to improve iron $(\mathrm{Fe})$ status among adolescent girls in Bangladesh-study protocol for a double-blind community-based randomized controlled trial. Trials, 20: 251. https://doi.org/10.1186/s13063-019-3309-4

Zhao,F.J.,R.E.Hamon and M.J.McLaughlin.2001. Root exudates of the hyperaccumulator Thlaspi caerulescens do not enhance metal mobilization. New Phytol., 151: 613-620. https://doi. org/10.1046/j.0028-646x.2001.00213.x 